\title{
PENGARUH PENAMBAHAN MONO-ASILGLISEROL (MAG) SEBAGAI EMULSIFIER PRODUK BAKERY
}

\section{THE EFFECTS OF MONO-ACYLGLYCEROL (MAG) ADDITION AS EMULSIFIERS OF BAKERY PRODUCT}

\author{
Dwi Setyaningsih",2), Jihan Suraya $^{1)}$, dan Syafira Salsabila ${ }^{2)}$ \\ ${ }^{1)}$ Departemen Teknologi Industri Pertanian, Fakultas Teknologi Pertanian, Institut Pertanian Bogor \\ Kampus IPB Dramaga, Bogor 16680, Indonesia \\ E-mail: dwisetyaningsih@apps.ipb.ac.id \\ ${ }^{2}$ Surfactant and Bioenergy Research Center, LPPM IPB University \\ Baranangsiang Campus of IPB, Bogor 16153, Indonesia
}

Makalah: Diterima 15 Desember 2020; Diperbaiki 28 Juli 2021; Disetujui 15 Agustus 2021

\begin{abstract}
Mono-acylglycerol (MAG) is the most used type of emulsifier in food industry. The need for domestic emulsifiers increases each year with an average value of $4 \%$, so that the development of MAG as an emulsifier has good prospects. This study aimed to determine the best concentration of MAG as bakery products emulsifier such as sponge cake $(2 \%, 2.5 \%, 3 \%)$, white bread $(0.5 \%, 1 \%, 1.5 \%)$, and cookies $(0.8 \%, 1.6 \%, 3.2 \%)$, and to know the characteristics differences of bakery products between synthesized MAG and commercial emulsifier. MAG was synthesized through the esterification process of coomercial glycerol from the byproducts of making biodiesel and palm fatty acid distillate from the byproducts of crude oil purification at a temperature of $150^{\circ} \mathrm{C}, 90$ minutes time, and a molar ratio of PFAD:glycerol 1:6. The best MAG concentrations for sponge cake were $2.5 \%$ based on physical characteristics and $3 \%$ based on organoleptics. The best MAG concentration for white bread was $1 \%$ indicate by its swelling dimensions. The best MAG concentration for cookie was $1.6 \%$ indicated by its swelling power that affects the crispness. The addition of MAG as emulsifier produces good characteristics and equivalent to commercial MAG in several aspects of bakery product quality.
\end{abstract}

Keywords: bakery, emulsifier, mono-acylglycerol, organoleptics, swelling powder

\section{ABSTRAK}

Mono-asilgliserol (MAG) termasuk jenis emulsifier yang paling banyak digunakan dalam industri pangan. Kebutuhan emulsifier dalam negeri meningkat setiap tahun dengan nilai rata-rata $4 \%$, sehingga pengembangan MAG sebagai emulsifier memiliki prospek yang baik. MAG dapat memberikan stabilitas emulsi, mengendalikan polimorfisme lemak, memperbaiki tekstur produk, dan meningkatkan aglomerasi lemak. Penelitian ini bertujuan mengetahui konsentrasi terbaik MAG sebagai emulsifier produk bakery seperti sponge cake $(2 \% ; 2,5 \% ; 3 \%)$, roti tawar $(0,5 \% ; 1 \% ; 1,5 \%)$, dan cookies $(0,8 \% ; 1,6 \% ; 3,2 \%)$, serta mengetahui perbedaan karakteristik mutu produk bakery dengan MAG hasil riset dan emulsifier komersial. MAG disintesis melalui proses esterifikasi gliserol dari hasil samping pembuatan biodiesel dan palm fatty acid distillate dari hasil samping pemurnian crude palm oil dengan suhu $150^{\circ} \mathrm{C}$, waktu 90 menit, dan rasio molar PFAD:gliserol 1:6. Konsentrasi MAG terbaik produk sponge cake yaitu 2,5\% berdasarkan hasil uji karakteristik fisik dan 3\% berdasarkan organoleptik. Konsentrasi terbaik MAG pada produk roti yakni $1 \%$ yang ditandai dengan dihasilkannya roti dengan volume yang lebih mengembang. Konsentrasi terbaik MAG pada produk cookies yakni MAG 1,6\% yang ditandai dengan dihasilkannya cookies dengan volume yang lebih mengembang yang juga mempengaruhi tingkat kerenyahan produk. Penambahan MAG menghasilkan karakteristik yang baik dan setara dengan emulsifier komersial pada beberapa aspek mutu produk bakery.

Kata kunci: bakery, emulsifier, mono-asilgliserol, organoleptik, pengembang

\section{PENDAHULUAN}

M-DAG termasuk jenis emulsifier yang paling banyak digunakan dalam industri pangan sebagai bahan pengemulsi dan penstabil pada produk-produk pangan dan kosmetika (Hasenhuettl, 2008). Menurut Rumondang et al. (2016), kebutuhan emulsifier dalam negeri meningkat dengan nilai rata-rata $4 \%$ setiap tahun. Sekitar $70 \%$ emulsifier yang digunakan di industri pangan adalah mono-asilgliserol dengan status GRAS (Generally Recognize as Safe), yaitu menggunakan bahan dan proses yang aman digunakan pada produk makanan (Setyaningsih, 2016).

M-DAG dapat dihasilkan dari proses esterifikasi gliserol dan asam lemak bebas (O'Brien, 2009). M-DAG yang digunakan pada penelitian ini disintesis menggunakan gliserol komersial dengan 
kemurnian 99,7\% yang merupakan hasil samping pembuatan biodiesel dan asam lemak bebas berupa palm fatty acid distillate (PFAD) yang merupakan hasil samping proses pemurnian crude palm oil (CPO).

Menurut Ferretti et al. (2018), M-DAG tersusun atas kombinasi molekul hidrofilik dan hidrofobik yang dapat membantu zat hidrofilik bercampur dengan lipofilik. Adanya gugus tersebut menyebabkan M-DAG dapat dijadikan sebagai emulsifier. Emulsifier sangat besar peranannya dalam menstabilkan suatu emulsi. M-DAG terdiri dari dua fraksi asilgliserol, yaitu mono-asilgliserol (MAG) dan diasilgliserol (DAG). M-DAG hasil riset yang digunakan pada penelitian ini terdiri dari kandungan MAG sebesar 93,29\% dan DAG sebesar 6,71\%.

Menurut Cheng et al. (2005), M-DAG secara umum berisi campuran dari 40-48\% MAG, 30-40\% DAG, $5-10 \%$ TAG, 0,2-9\% asam lemak dan 4-8\% gliserol. M-DAG hasil riset ini selanjutnya akan disebut sebagai MAG karena kandungan MAG yang jauh lebih besar. MAG secara luas digunakan dalam produk bakery, margarine, produk susu, dan confectionary karena sifat emulsifikasi, stabilisasi, dan conditioning (Damstrup et al.,,2005).

Produk bakery merupakan salah satu produk pangan yang banyak digemari oleh masyarakat. Produk bakery merupakan produk pangan yang secara luas diproduksi dan dikonsumsi setelah dairy produk (Majeed et al., 2018). Menurut Dziezak (1988), MAG dapat memberikan stabilitas emulsi, mengendalikan polimorfisme lemak, memperbaiki tekstur produk, dan meningkatkan aglomerasi lemak.

Menurut $\mathrm{Fu}$ et al. (2018), MAG dan DAG dapat mendorong inklusi dan retensi gas $\mathrm{CO}_{2}$ dalam adonan sehingga meningkatkan volume dan struktur produk. Pada cake dan cookies, gas $\mathrm{CO}_{2}$ dihasilkan dari proses pengocokan telur. Sedangkan pada roti, gas $\mathrm{CO}_{2}$ dihasilkan saat proses fermentasi. Selain itu, emulsifier dapat memperkuat jaringan gluten sehingga kemampuan gluten untuk menahan gas $\mathrm{CO}_{2}$ menjadi lebih kuat dan dihasilkan adonan yang lebih mengembang. Adonan yang mengembang tersebut menjadikan tekstur pada produk bakery menjadi lebih lembut.

Penelitian ini bertujuan untuk mengidentifikasi karakteristik fisik dan organoleptik sponge cake, roti tawar, dan cookies dengan emulsifier MAG, mengetahui perbedaan karakteristik produk yang dihasilkan dengan emulsifier MAG dan emulsifier komersial, dan menentukan konsentrasi MAG terbaik sebagai bahan emulsifier produk sponge cake, roti tawar, dan cookies.

\section{BAHAN DAN METODE}

\section{Alat dan Bahan}

Peralatan yang digunakan adalah mangkuk plastik, sodet plastik, kertas saring, mixer, loyang aluminium bundar berdiamater $22 \mathrm{~cm}$ dan tinggi 4 $\mathrm{cm}$, cetakan adonan berbentuk casino, loyang roti, kuas roti, mixer, oven, cawan aluminium (pengujian kadar air), pengatur waktu, pengatur suhu, neraca, termometer, penggaris, pisau, sendok, panci/teflon (memanaskan margarin), saringan, sarung tangan, dan serbet. Bahan yang digunakan untuk tiap jenis produk ialah sebagai berikut.

Bahan yang digunakan pada produk sponge cake adalah $33,8 \%$ telur, $16,9 \%$ tepung terigu, $22 \%$ gula pasir, 4,2\% maizena, 4,2\% susu bubuk, $16,9 \%$ margarin, 0,2\% baking powder, 0,4\% vanili bubuk, dan 0,$3 ; 0,4 ; 0,5 \mathrm{~g}$ emulsifier per total bahan. Bahan yang digunakan pada produk roti tawar adalah 53,5\% tepung terigu, $33,5 \%$ air, $0,7 \%$ ragi, $0,2 \%$ garam, $1,4 \%$ susu bubuk, 4,3\% margarin, $4,8 \%$ gula pasir, dan 0,$3 ; 0,5 ; 0,8 \%$ emulsifier per total bahan. Bahan yang digunakan pada produk cookies adalah 37,6\% tepung terigu, $30 \%$ gula putih halus, $1,2 \%$ maizena, $16,8 \%$ margarin, $10,8 \%$ telur, $0,4 \%$ baking powder, $0,7 \%$ vanili bubuk, $0,4 \%$ garam, dan 0,$3 ; 0,6 ; 1,2 \%$ emulsifier per total bahan.

\section{Pembuatan Mono-Asilgliserol (MAG) \\ Pembuatan MAG diawali dengan} melakukan sintesis M-DAG kasar dengan esterifikasi (modifikasi Mardaweni et al. (2017)). Esterifikasi dilakukan dengan mereaksikan PFAD dan gliserol dalam reaktor menggunakan katalis pTSA 1,5\% dari bobot PFAD dan adsorben zeolit 5\% (b/b), proses berlangsung secara vakum dengan suhu $150^{\circ} \mathrm{C}$ dengan waktu 90 menit dan rasio molar PFAD:gliserol 1:6. Pada proses ini M-DAG yang dihasilkan berupa M-DAG kasar sehingga selanjutnya perlu dilakukan proses pemurnian.

Selanjutnya dilakukan pemurnian terhadap MDAG kasar yang dihasilkan (modifikasi Setyaningsih et al (2016)). Proses pemurnian terhadap M-DAG menggunakan tambahan campuran pelarut heksanaetanol dengan rasio volume 1:1 ke dalam M-DAG kasar dengan perbandingan MDAG kasar dan pelarut 1:5. Selanjutnya dilakukan proses netralisasi dengan menambahkan $\mathrm{NaHCO}_{3} \quad 0,3 \%$ (b/b) M-DAG kasar untuk menetralkan asam lemak dan residu katalis. Kelebihan basa yang dihasilkan kemudian akan diendapkan, fase pelarut akan dikristalisasi pada suhu $6^{\circ} \mathrm{C}$ selama 72 jam. Proses kristalisasi akan menghasilkan padatan M-DAG yang dipisahkan melalui proses filtrasi vakum, setelah itu dilanjutkan dengan pencucian menggunakan etanol teknis. Rendemen lalu dihitung sebagai jumlah M-DAG kasar yang masuk dan M-DAG yang dihasilkan.

\section{Pembuatan Produk Bakery \\ Pembuatan Sponge Cake}

Pembuatan sponge cake diawali dengan pengocokan telur hingga berbusa dengan mixer kecepatan sedang. Setelah itu ditambahkan gula pasir secara perlahan selama pengocokan berlangsung 
sampai gula larut dan adonan mengembang. Lalu masukkan bahan tambahan berupa vanili bubuk, baking powder, dan emulsifier selama proses mixing berlangsung hingga bahan larut dan tercampur merata dengan adonan. Setelah itu masukkan bahan kering seperti tepung terigu, maizena, dan susu bubuk ke dalam adonan basah sambil diaduk secara perlahan dengan sodet plastik sampai bahan tercampur merata, lalu ditambahkan margarin yang telah dicairkan. Pengadukan dilakukan dari bawah ke atas untuk menjaga adonan agar tetap mengembang. Adonan kemudian dimasukkan ke dalam loyang yang telah diolesi margarin. Setelah itu, loyang dimasukkan ke dalam oven pemanggang dengan suhu sekitar $180^{\circ} \mathrm{C}$ selama 30 menit. Perlakuan konsentrasi MAG yang digunakan yaitu $2 \% ; 2,5 \%$; dan $3 \%$ dari total tepung terigu yang digunakan.

\section{Pembuatan Roti Tawar}

Pembuatan roti tawar dilakukan dengan metode straight dough dengan mencampurkan semua bahan mulai dari tepung terigu, air, gula, margarin, susu bubuk, ragi, garam, dan emulsifier secara langsung dan diuleni. Perlakuan konsentrasi MAG yang digunakan yaitu $0,5 \% ; 1 \%$; dan $1,5 \%$ dari total tepung yang digunakan. Setelah adonan terbentuk, adonan dibulatkan lalu diamkan sambil ditutup dengan kain sampai adonan mengembang selama 60 menit. Setelah itu, gilas roti di atas bidang datar menjadi bentuk persegi panjang sampai tipis. Adonan yang sudah tipis kemudian digulung dan dimasukkan ke dalam loyang yang sudah diolesi margarin. Selanjutnya adonan ditutup dan didiamkan kembali sampai adonan mengembang selama 50 menit. Setelah adonan mengembang, masukkan loyang berisi adonan ke dalam oven untuk proses pemanggangan selama 40 menit dengan suhu $180^{\circ} \mathrm{C}$. Setelah matang, roti dikeluarkan dari loyang dan didiamkan sampai suhu internal mencapai $30^{\circ} \mathrm{C}$.

\section{Pembuatan Cookies}

Pembuatan cookies diawali dengan mencampur bahan-bahan dan kemudian mengaduknya. Pencampuran bahan dilakukan dengan menggunakanm metode krim, di mana pencampuran akan dibagi ke dalam dua tahapan. Pada tahap pertama akan dilakukan pencampuran margarin, gula putih halus, dan telur lalu diaduk hingga rata menggunakan mixer. Tahap kedua dilakukan penambahan garam, tepung terigu, maizena, vanili bubuk, baking powder, dan emulsifier hingga tercampur rata dan terbentuk adonan. Perlakuan konsentrasi emulsifier yang digunakan yaitu $0,8 \%$; $1,6 \%$; dan $3,2 \%$ dari total tepung terigu yang digunakan. Selanjutnya adalah tahap pembentukan adonan menjadi kecil-kecil khas cookies di atas loyang. Tahap terakhir yaitu tahap pemanggangan pada suhu $150-200^{\circ} \mathrm{C}$ selama \pm 10 menit.

\section{Pengujian Sampel}

Produk bakery dibuat dengan 4 sampel perlakuan, di mana satu perlakuan menggunakan emulsifier komersial dan tiga perlakuan lainnya menggunakan MAG hasil riset dengan konsentrasi yang disesuaikan. Produk sponge cake dianalisis mutu fisiknya dengan analisis tinggi tengah (Fadhilah, 2017), analisis daya kembang (Sulistianing, 1995), analisis stabilitas daya kembang (Sulistianing, 1995), uji kadar air (AOAC, 2005), analisis ukuran pori (Pusuma et al., 2018), serta uji organoleptik (SNI 2006) berupa uji scoring untuk parameter warna, struktur pori, aroma, sifat remah, tekstur dan rasa cake. Pada produk roti dilakukan analisis pengukuran dimensi, analisis warna, aroma, rasa, dan tekstur, analisis ukuran pori (Pusuma et al., 2018), dan ketahanan umur simpan (Susiwi, 2009). Pada produk cookies dilakukan analisis daya kembang (Sulistianing, 1995), analisis warna, aroma, rasa, dan tekstur, serta analisis ukuran pori (Pusuma et al., 2018).

Perbedaan analisis pada ketiga produk disebabkan adanya kendala akibat pandemi Covid-19 sehingga pada produk roti tawar dan cookies hanya dilakukan pengamatan terhadap parameter dengan prosedur pengujian yang bisa dilakukan di rumah. Hal tersebut menyebabkan parameter pengujian produk yang dilakukan berbeda-beda.

\section{Analisis Data}

Analisis data dilakukan menggunakan uji keragaman ANOVA pada taraf 0,05. Pengolahan data dilakukan dengan bantuan software microsoft excel. Data yang dianalisis berupa data organoleptik sponge cake, data ukuran pori sponge cake, data ukuran pori cookies, dan data ukuran pori roti tawar. Pengolahan data dengan ANOVA ini bertujuan untuk mengetahui variabilitas atau keseragaman data dengan cara membandingkan rata-rata data sampel pengujian. Dalam penelitian ini, terdapat empat data yang akan diujikan sesuai dengan perlakuan konsentrasi emulsifier yang digunakan. Jika uji keragaman menunjukkan data yang berbeda nyata, maka dilanjutkan dengan uji Duncan untuk mengetahui data yang berbeda tersebut.

\section{HASIL DAN PEMBAHASAN}

\section{Pembuatan Mono-Asilgliserol}

Proses pembuatan mono-asilgliserol (MAG) diawali dengan melakukan sintesis M-DAG kasar. Proses sintesis dapat dilakukan dengan tiga cara, antara lain proses hidrolisis dengan menggunakan enzim, esterifikasi, dan transesterifikasi. Cara yang digunakan pada penelitian ini yaitu menggunakan proses esterifikasi. Proses esterifikasi dilakukan dengan mereaksikan palm fatty acid distillate (PFAD) dan gliserol dalam reaktor dengan bantuan katalis pTSA $1,5 \%$ dari bobot PFAD dan adsorben zeolit 5\% (b/b), proses berlangsung secara vakum dengan suhu 
$150^{\circ} \mathrm{C}$ dengan waktu 90 menit, dan rasio molar PFAD:gliserol 1:6 (Setyaningsih et al., 2021). Produk yang dihasilkan dari reaksi ini yaitu mono-asilgliserol (MAG), diasilgliserol (DAG), dan triasilgliserol (TAG).

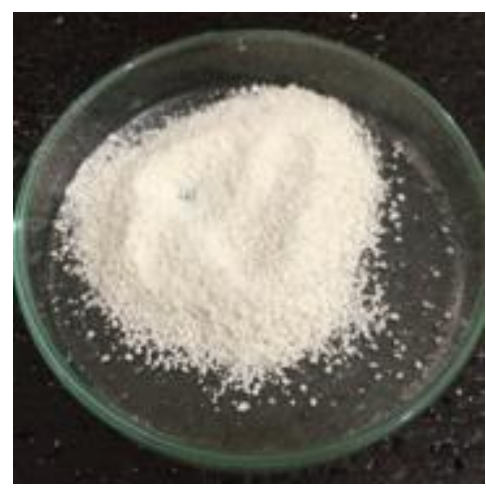

Gambar 1. M-DAG hasil pemurnian

Proses pemurnian dilakukan untuk meningkatkan kemurnian M-DAG di atas $90 \%$. Menurut Gibon et al. (2007), tujuan dari proses pemurnian adalah untuk menghilangkan komponenkomponen yang bersifat mengganggu di dalam produk dan juga untuk meminimalisir kerusakan. Komponen yang akan dihilangkan pada proses pemurnian ini antara lain asam lemak bebas dan TAG. Menurut Ketaren (2008), produk minyak harus memiliki kadar asam lemak bebas serendah mungkin karena asam lemak bebas dapat menyebabkan ketengikan akibat oksidasi.

Selanjutya dilakukan proses kristalisasi untuk memperoleh karakter akhir M-DAG yang diinginkan. M-DAG akhir yang dihasilkan terdiri dari komponen MAG sebesar 93,29\% dan DAG sebesar 6,71\%. Karakteristik fisik produk MAG akhir yang dihasilkan tidak memiliki aroma, bertekstur kering, dan berwarna putih. Karakteristik kimia MAG disajikan pada Tabel 1 .

\section{Aplikasi MAG dalam Pembuatan Sponge cake \\ Tinggi Tengah Sponge cake}

Tinggi tengah sponge cake dipengaruhi volume adonan yang dihasilkan dari proses pengocokan. Tingkat pengembangan adonan dipengaruhi banyak busa yang terbentuk selama proses pengocokan telur dengan mixer. Jika pada kondisi volume mengembang busa yang terbentuk dipanaskan, maka akan terjadi denaturasi protein sehingga busa yang terbentuk menjadi lebih stabil dan terjadi pengembangan adonan (Suhardi, 1988).

Tabel 1. Karakteristik kimia MAG yang dihasilkan

\begin{tabular}{lcc}
\hline Parameter & Satuan & Nilai \\
\hline Kadar asam lemak & & \\
bebas & $\%$ & 0,51 \\
Titik leleh & ${ }^{\circ} \mathrm{C}$ & 57 \\
Nilai pH & - & 5 \\
Bilangan hidroksil & $\mathrm{mg} \mathrm{KOH} / \mathrm{g}$ & 349,3
\end{tabular}

Sumber : Setyaningsih et al., 2021

Berdasarkan Tabel 2, diketahui produk sponge cake dengan perlakuan emulsifier komersial memiliki ukuran tinggi tengah yang paling besar. Tekstur adonan cake yang terbentuk saat penambahan emulsifier komersial lebih kohesif dan homogen dibandingkan pada saat penambahan MAG. Menurut Fitasari (2009), penambahan tepung terigu dapat menyebabkan kadar air terserap oleh pati dikarenakan tepung berwujud padat, sehingga semakin banyak kandungan padatan yang ditambahkan akan membuat kadar air mengalami penurunan. Adonan yang lebih kohesif dapat lebih mempertahankan volumenya sehingga hanya mengalami sedikit penurunan volume ketika penambahan bahan padat.

Adonan cake yang lebih kompak yang dihasilkan dari penambahan emulsifier komersial dapat disebabkan oleh kandungan sorbitol yang terdapat di dalam emulsifier komersial. Menurut Majeed et al. (2018), sorbitol dapat meningkatkan cohesiveness adonan cake. Cohesiveness menunjukkan kemampuan produk untuk menahan tekanan kedua setelah dilakukan penekanan pertama (Roshental, 1999). Dalam hal ini, tekanan kedua yang dimaksud yaitu penambahan bahan padat pada adonan cake. Hasil penelitian menunjukkan konsentrasi MAG yang menghasilkan tinggi tengah cake paling besar yaitu $2 \%$ dan $2,5 \%$.

\section{Daya Kembang Sponge cake}

Daya kembang sponge cake dipengaruhi oleh agen pembentuk gas seperti emulsifier. Menurut Bornscheuer (1995), MAG dengan kemurnian yang tinggi memiliki sifat emulsifikasi yang lebih baik dibandingkan dengan campuran asilgliserol.

Tabel 2. Karakteristik fisik sponge cake

\begin{tabular}{lcccc}
\hline Perlakuan & $\begin{array}{c}\text { Tinggi Tengah } \\
(\mathbf{c m})\end{array}$ & $\begin{array}{c}\text { Daya Kembang } \\
(\boldsymbol{\%})\end{array}$ & $\begin{array}{c}\text { Stabilitas Daya } \\
\text { Kembang }(\boldsymbol{\%})\end{array}$ & $\begin{array}{c}\text { Kadar Air } \\
(\boldsymbol{\%})\end{array}$ \\
\hline Komersial 4\% & 9,6 & 86,69 & 85,89 & 22,28 \\
MAG 2\% & 6,6 & 88,22 & 92,34 & 21,80 \\
MAG 2,5\% & 6,6 & 95,69 & 92,94 & 20,86 \\
MAG 3\% & 6,5 & 75,30 & 92,72 & 21,69 \\
\hline
\end{tabular}

Keterangan: Setiap data merupakan rerata dari 2 ulangan 
Sifat emulsifikasi tersebut akan mempengaruhi daya kembang dengan kemampuan MAG untuk mengikat gas $\mathrm{CO}_{2}$ yang terbentuk selama proses pemanggangan sehingga cake yang dihasilkan lebih mengembang. Data tinggi tengah cake menunjukkan perlakuan komersial menghasilkan tinggi tengah terbesar, namun setelah dilakukan pengukuran daya kembang diperoleh MAG 2,5\% menghasilkan cake dengan daya kembang yang paling besar. Adonan yang lebih kohesif pada perlakuan emulsifier komersial menunjukkan tekstur adonan yang lebih kental dibandingkan dengan MAG.

Menurut Mancebo et al. (2015) dalam Pratama dan Nendra (2017), adonan yang memiliki viskositas tinggi memiliki kecenderungan lebih sedikit untuk mengembang. Pernyataan tersebut sesuai dengan hasil penelitian, di mana tinggi adonan cake sebelum dan sesudah pemanggangan pada perlakuan MAG 2,5\% menunjukkan selisih yang lebih besar yang menandakan cake yang dihasilkan lebih mengembang.

\section{Stabilitas Daya Kembang Sponge cake}

Stabilitas daya kembang sponge cake merupakan keadaan di mana sponge cake akan tetap mempertahankan daya kembangnya setelah didiamkan dalam waktu tertentu, hingga suhu cake tersebut mencapai suhu yang sama dengan suhu ruangan (Hajrah et al. 2019). Stabilitas daya kembang dipengaruhi oleh sifat reologi adonan cake yang terbentuk. Menurut Dobraszczyk et al. (2003), sifat reologi adonan yang baik mampu menghasilkan stabilitas gelembung gas yang baik

Berdasarkan data pada Tabel 2 diketahui sponge cake dengan perlakuan MAG 2,5\% memiliki stabilitas daya kembang yang paling baik. Sifat reologi berkorelasi dengan stabilitas ketahanan gelembung gas di dalam cake pada saat proses pemanggangan maupun saat proses pemanggangan berakhir. Hal ini berhubungan dengan peran emulsifier sebagai agen pembentuk gas pada adonan. Gelembung gas yang stabil akan membentuk struktur akhir dan volume cake yang baik. Menurut Dziezak (1988), MAG dapat memberikan stabilitas emulsi pada produk, sehingga diperoleh hasil cake dengan tinggi yang lebih stabil setelah didiamkan selama beberapa jam.

\section{Kadar Air Sponge cake}

Kadar air menentukan banyak air yang teruapkan pada sampel selama proses pengeringan sampai sampel memiliki bobot yang konstan. Semakin tinggi kadar air menunjukkan semakin banyak air yang teruapkan pada proses pengeringan, air yang dapat diuapkan termasuk dalam golongan air bebas yang tidak terikat secara kuat (Praseptiangga $e t$ al. 2016).

Keempat perlakuan memiliki kadar air di bawah 40\% atau memenuhi standar SNI (1995). Berdasarkan data pada Tabel 2 diketahui MAG 2,5\% menunjukkan kadar air yang paling rendah. Menurut Musfiroh (2009), kandungan air dalam bahan pangan memiliki peranan yang sangat penting karena menentukan acceptability, kesegaran, dan sangat berpengaruh pada masa simpan bahan pangan, karena air dapat mempengaruhi tekstur, kenampakan, dan cita rasa makanan. Semakin rendah kadar air maka akan semakin memperpanjang umur simpan produk.

\section{Ukuran Pori Sponge cake}

Pori merupakan lubang-lubang kecil yang terbentuk karena adanya gas $\mathrm{CO}_{2}$ yang terperangkap dalam adonan saat dipanggang. Proses aerasi yang terjadi selama pengadonan akan mempengaruhi keseragaman pori yang dihasilkan sehingga pori yang dihasilkan akan sangat beragam. Menurut Handleman (1961), dengan penambahan emulsifier, maka akan lebih banyak sel udara dengan ukuran yang lebih seragam yang dihasilkan dari proses pencampuran dan bertindak sebagai tempat nukleasi untuk gas terlarut.

Menurut $\mathrm{Fu}$ et al. (2018), MAG dapat mendorong inklusi dan retensi udara dalam adonan cake sehingga dapat meningkatkan struktur crumb pada cake. Pengukuran pori dilakukan dengan mengambil 10 sampel acak pori pada tiap produk roti untuk diukur diameternya (mm) menggunakan penggaris. Analisis data dengan ANOVA menunjukkan perbedaan ukuran pori keempat perlakuan tidak berbeda nyata.

Berdasarkan data pada Gambar 2 diperoleh ukuran pori sponge cake perlakuan emulsifier komersial menunjukkan ukuran pori yang paling besar. Menurut Giannone et al. (2016), pori yang kecil dan seragam dapat menghambat laju staling pada cake. Berdasarkan data diperoleh sponge cake dengan MAG menunjukkan ukuran pori yang lebih kecil dan terlihat lebih seragam, namun pori tersebut tidak tersebar merata di seluruh bagian crumb sponge cake yang menunjukkan pori yang terbentuk tidak banyak. Hal tersebut membuat tekstur akhir cake yang dihasilkan sedikit lebih keras dibandingkan emulsifier komersial. 


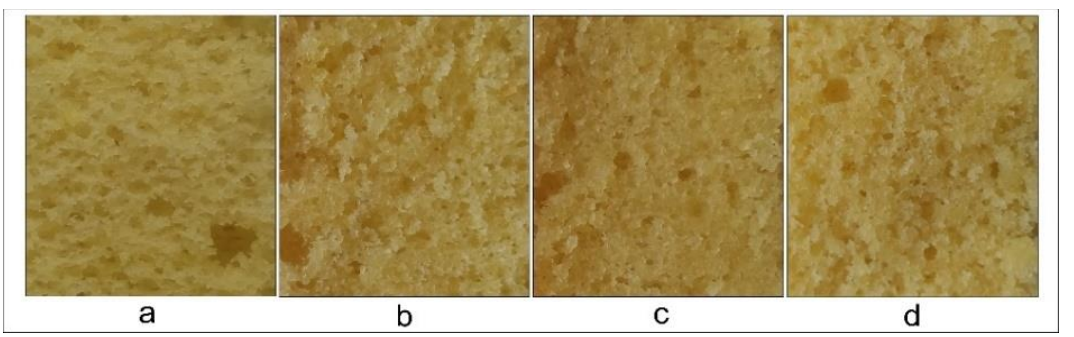

Gambar 1. Pori sponge cake (a) komersial, (b) MAG 2\%, (c) MAG 2,5\%, (d) MAG 3\%

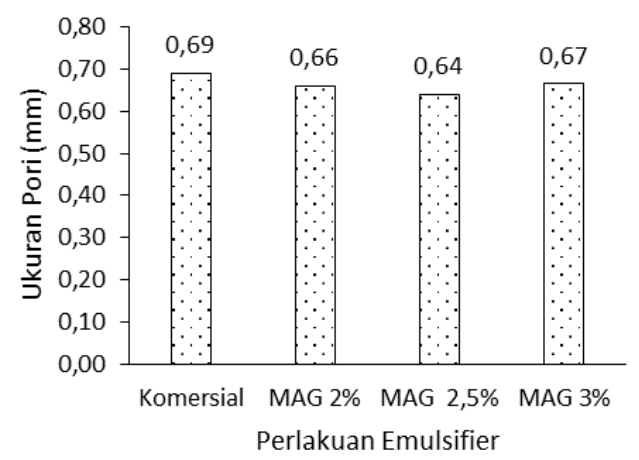

Gambar 2. Grafik pengaruh perlakuan emulsifier terhadap rerata ukuran diameter pori $(\mathrm{mm})$ produk sponge cake

\section{Uji Organoleptik Sponge cake}

Uji organoleptik merupakan cara untuk mengetahui respon panelis terhadap karakter sensori produk sponge cake. Uji organoleptik yang digunakan pada penelitian ini yaitu uji scoring, di mana panelis diminta untuk menilai sifat sensori produk secara spesifik dengan deskripsi nilai yang disediakan pada form atribut. Pengujian dilakukan dengan enam parameter mutu seperti struktur pori, warna, aroma, sifat remah, tekstur, dan rasa pada sponge cake dengan range nilai 1-5 yang akan dinilai oleh 30 orang panelis. Parameter yang dipilih merupakan parameter umum dalam menilai produk sponge cake sehingga dapat diketahui pengaruh penambahan MAG terhadap parameter umum sponge cake secara keseluruhan.

Sponge cake pada prosesnya langsung mengocok telur utuh sehingga warna adonan yang dihasilkan sangat kuning dan akan berpengaruh pada hasil cake setelah dipanggang (Suhardjito, 2003). Berdasarkan data diketahui rerata panelis menilai sponge cake perlakuan emulsifier komersial dengan konsentrasi $4 \%$ memiliki warna yang paling baik, yaitu kuning cerah. Analisis data dengan ANOVA pada taraf 0,05 terhadap perlakuan emulsifier menujukkan adanya pengaruh nyata pada warna cake.

Struktur pori sangat dipengaruhi kemampuan pembentukan gas dan penahanan gas selama proses pengovenan (Mudjisihono et al., 2000). Berdasarkan data diketahui rerata panelis menilai sponge cake perlakuan MAG 3\% memiliki struktur pori yang paling baik, yaitu berukuran kecil dengan struktur rapat. Analisis data dengan ANOVA pada taraf 0,05 terhadap perlakuan emulsifier menujukkan adanya pengaruh nyata pada struktur pori cake.

Aroma akhir khas sponge cake terbentuk selama proses pemanggangan. Selama pemanggangan senyawa-senyawa volatil menguap sehingga aroma bahan dasar sebagian besar hilang akibat pemasakan (Febrianto et al., 2014). Berdasarkan data diketahui rerata panelis menilai sponge cake perlakuan emulsifier komersial memiliki aroma yang paling baik, yaitu aroma normal khas cake. Pada emulsifier MAG, konsentrasi dengan nilai aroma tertinggi yaitu 2,5\%. Analisis data dengan ANOVA pada taraf 0,05 terhadap perlakuan emulsifier tidak memiliki pengaruh nyata pada aroma cake.

Menurut Rumini (2010), sponge cake memiliki sifat remah yang cenderung kasar ketika dipotong. Sifat remah yang cenderung kasar memberi sponge cake bentuk yang lebih kokoh sehingga remah-remah pada sponge cake tidak mudah terlepas baik saat dipotong maupun dipegang dengan tangan. Berdasarkan data diketahui rerata panelis menilai sponge cake perlakuan MAG 3\% memiliki sifat remah yang paling baik, yaitu tidak ada remah cake yang terlepas dengan alur crumb yang seragam dan rapat. Analisis data dengan ANOVA pada taraf 0,05 terhadap perlakuan emulsifier menujukkan adanya pengaruh nyata pada sifat remah cake.

Parameter tekstur pada uji scoring ini difokuskan pada penerimaan rangsangan mulut, sedangkan perabaan dengan jari masuk di parameter sifat remah. Sponge cake memiliki tekstur yang agak kasar, kurang lentur dan cenderung beremah apabila dipotong (Rumini, 2010). Berdasarkan data diketahui rerata panelis menilai sponge cake perlakuan emulsifier komersial memiliki tekstur yang paling baik, yaitu sangat lembut dan lembab. Analisis data dengan ANOVA pada taraf 0,05 terhadap perlakuan emulsifier menujukkan adanya pengaruh nyata pada tekstur cake.

Berdasarkan data diketahui rerata panelis menilai sponge cake perlakuan emulsifier komersial memiliki rasa yang paling baik dibandingkan dengan cake dengan perlakuan MAG, yaitu rasa normal khas cake. Pada penelitian, emulsifier komersial yang digunakan yaitu dikenal dengan merk dagang Ovalett. 
Menurut Hartomo dan Widiatmoko (1993), Ovalett tersusun atas mono dan digliserida asam lemak nabati dan sorbitol. Kandungan bahan lain itulah yang menyebabkan cake dengan emulsifier komersial memiliki rasa yang lebih baik dibandingkan dengan penggunaan MAG hasil sintesis. Analisis data dengan ANOVA pada taraf 0,05 terhadap perlakuan emulsifier tidak memiliki pengaruh nyata terhadap rasa cake. Berdasarkan data pada Tabel 3 diketahui MAG 3\% menghasilkan total nilai organoleptik yang paling besar.

\section{Aplikasi MAG dalam Pembuatan Roti Tawar Ukuran Dimensi Roti Tawar}

Salah satu parameter mutu roti dapat dilihat dari ukuran yang dihasilkan. Roti berukuran besar sebagai hasil dari proses pengembangan akibat adanya kandungan gluten yang dapat menahan gas yang dihasilkan selama proses fermentasi berlangsung. Gandikota dan MacRitchie (2005) menyatakan bahwa kapasitas pengembangan adonan ditentukan oleh struktur sel gas dan stabilitas sel gas. Pengukuran dimensi dilakukan dengan mengukur tinggi roti, lebar roti, dan keliling roti dari dua arah, baik secara vertikal maupun horizontal. Pengukuran tidak dilakukan dengan menghitung volume dikarenakan bentuk permukaan roti yang dihasilkan tidak rata.

Berdasarkan data pada Tabel 4, secara umum perlakuan komersial dengan konsentrasi $1 \%$ menghasilkan roti dengan ukuran yang paling besar. Perlakuan MAG 1\% menghasilkan ukuran yang lebih besar dan lebih mendekati ukuran yang dihasilkan emulsifier komersial dibandingkan dengan konsentrasi MAG lainnya. Hasil ini menunjukkan bahwa perlakuan MAG terbaik yang menghasilkan roti yang paling mengembang yaitu MAG $1 \%$. Ukuran akhir produk roti tawar yang tidak terlalu berbeda ini dapat disebabkan kedua jenis emulsifier yang digunakan mengandung MAG dan DAG. Menurut Fu et al. (2018), MAG dan DAG sebagai emulsifier dapat mendorong inklusi dan retensi udara dalam adonan sehingga dapat meningkatkan volume produk.

Menurut Hartomo dan Widiatmoko (1993), Ovalett tersusun atas mono dan digliserida asam lemak nabati dan sorbitol. Kandungan bahan lain itulah yang menyebabkan cake dengan emulsifier komersial memiliki rasa yang lebih baik dibandingkan dengan penggunaan MAG hasil sintesis. Analisis data dengan ANOVA pada taraf 0,05 terhadap perlakuan emulsifier tidak memiliki pengaruh nyata terhadap rasa cake. Berdasarkan data pada Tabel 3 diketahui MAG 3\% menghasilkan total nilai organoleptik yang paling besar.

\section{Aplikasi MAG dalam Pembuatan Roti Tawar \\ Ukuran Dimensi Roti Tawar}

Salah satu parameter mutu roti dapat dilihat dari ukuran yang dihasilkan. Roti berukuran besar sebagai hasil dari proses pengembangan akibat adanya kandungan gluten yang dapat menahan gas yang dihasilkan selama proses fermentasi berlangsung. Gandikota dan MacRitchie (2005) menyatakan bahwa kapasitas pengembangan adonan ditentukan oleh struktur sel gas dan stabilitas sel gas. Pengukuran dimensi dilakukan dengan mengukur tinggi roti, lebar roti, dan keliling roti dari dua arah, baik secara vertikal maupun horizontal. Pengukuran tidak dilakukan dengan menghitung volume dikarenakan bentuk permukaan roti yang dihasilkan tidak rata.

Berdasarkan data pada Tabel 4, secara umum perlakuan komersial dengan konsentrasi $1 \%$ menghasilkan roti dengan ukuran yang paling besar. Perlakuan MAG 1\% menghasilkan ukuran yang lebih besar dan lebih mendekati ukuran yang dihasilkan emulsifier komersial dibandingkan dengan konsentrasi MAG lainnya. Hasil ini menunjukkan bahwa perlakuan MAG terbaik yang menghasilkan roti yang paling mengembang yaitu MAG $1 \%$. Ukuran akhir produk roti tawar yang tidak terlalu berbeda ini dapat disebabkan kedua jenis emulsifier yang digunakan mengandung MAG dan DAG. Menurut Fu et al. (2018), MAG dan DAG sebagai emulsifier dapat mendorong inklusi dan retensi udara dalam adonan sehingga dapat meningkatkan volume produk.

\section{Analisis Warna, Aroma, dan Rasa Roti Tawar}

Analisis warna, aroma, dan rasa roti tawar dilakukan melalui pengamatan mandiri. Warna merupakan parameter penting yang pertama dilihat oleh konsumen dalam memilih produk pangan. warna roti yang baik menurut Mudjajanto dan Yulianti (2004) ialah kuning kecoklatan untuk bagian crust atau kulit roti dan putih krem untuk bagian crumb atau remah roti. Pengujian dilakukan dengan pengamatan visual secara langsung pada keempat sampel produk.

Tabel 3. Karakteristik organoleptik sponge cake

\begin{tabular}{lcllllll}
\hline Perlakuan & Warna & Struktur Pori & Aroma & Sifat Remah & Tekstur & Rasa & Total \\
\hline Komersial & $4,23^{\mathrm{d}}$ & $1,83^{\mathrm{a}}$ & 3,27 & $2,92^{\mathrm{b}}$ & $3,88^{\mathrm{c}}$ & 3,57 & 19,68 \\
MAG 2\% & $3,37^{\mathrm{c}}$ & $3,88^{\mathrm{d}}$ & 2,97 & $4,08^{\mathrm{c}}$ & $2,65^{\mathrm{a}}$ & 3,00 & 19,95 \\
MAG 2.5\% & $3,32^{\mathrm{a}}$ & $3,70^{\mathrm{c}}$ & 3,01 & $4,05^{\mathrm{a}}$ & $2,42^{\mathrm{d}}$ & 2,93 & 19,44 \\
MAG 3\% & $3,57^{\mathrm{ab}}$ & $4,05^{\mathrm{b}}$ & 2,92 & $4,22^{\mathrm{c}}$ & $2,50^{\mathrm{b}}$ & 3,13 & 20,39 \\
\hline
\end{tabular}

Keterangan: Angka-angka yang diikuti notasi huruf yang tidak sama menunjukkan beda nyata berdasarkan uji lanjut Duncan pada taraf $95 \%$. 
Tabel 4. Ukuran dimensi roti tawar

\begin{tabular}{lccc}
\hline Perlakuan & Keliling Vertikal $(\mathbf{c m})$ & Keliling Horizontal $(\mathbf{c m})$ & Tinggi $(\mathbf{c m})$ \\
\hline Komersial 1\% & 52,0 & 54,9 & 13,5 \\
MAG 0,5\% & 45,9 & 52,9 & 12,9 \\
MAG 1\% & 47,2 & 53,6 & 13,0 \\
MAG 1.5\% & 46,5 & 53,0 & 13,0 \\
\hline
\end{tabular}

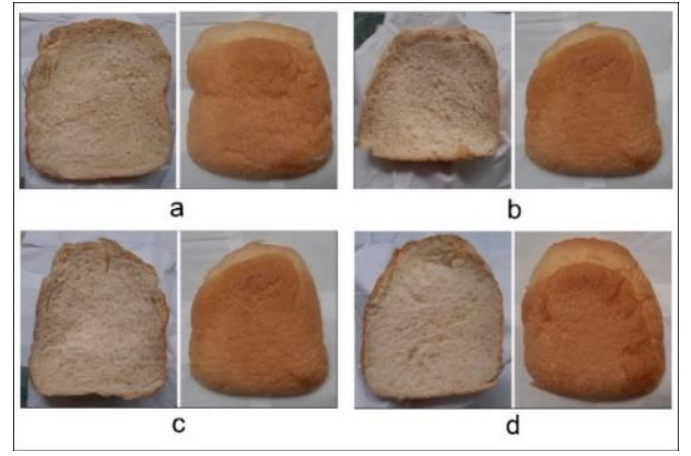

Gambar 3. Penampakan visual roti tawar (a) komersial, (b) MAG $1 \%$, (c) MAG $0,5 \%$, (d) MAG $1,5 \%$

Berdasarkan pengamatan pada bagian crumb, roti dengan perlakuan MAG menghasilkan warna yang lebih cerah dibandingkan dengan roti yang menggunakan emulsifier komersial. Hal ini dapat disebabkan oleh perbedaan warna emulsifier yang digunakan, di mana MAG memiliki warna putih, sedangkan emulsifier komersial yang digunakan berwarna kuning sehingga mempengaruhi warna akhir produk menjadi putih kusam pada bagian crumb. Pada bagian crust, keempat sampel roti menunjukkan warna kuning kecoklatan yang sama. Menurut Winarno (1992), warna kecoklatan disebabkan adanya reaksi maillard, yaitu reaksi antara gula pereduksi dan protein yang terkandung dalam bahan dan terjadi selama proses pemanggangan.

Selain warna, rasa dan aroma merupakan parameter mutu penting pada suatu produk pangan. Menurut SNI (1995), rasa dan aroma roti tawar harus normal (khas roti). Menurut Mudjajanto dan Yulianti (2004), kriteria roti tawar yang baik memiliki rasa gurih agak asin dan aroma harum (khas roti). Aroma khas dari roti tawar terbentuk dari proses fermentasi menggunakan ragi yang menghasilkan alkohol. Pada keempat perlakuan emulsifier diperoleh rasa dan aroma normal khas roti dengan sedikit rasa asin karena faktor penambahan garam pada adonan. Hal ini menunjukkan bahwa tidak terdapat pengaruh spesifik pada rasa,dan aroma berdasarkan perbedaan perlakuan emulsifier yang digunakan.

\section{Pengamatan Tekstur Roti Tawar}

Tekstur merupakan parameter yang juga menentukan penerimaan konsumen terhadap roti tawar. Kegunaan mono-asilgliserol dalam industri pangan adalah sebagai surfaktan, emulsifier zat untuk pembentukan tekstur pada adonan roti (Elizabeth dan Boyle, 1997). Roti tawar yang baik ialah yang memiliki tekstur yang lembut dan empuk. Menurut Mudjajanto dan Yulianti (2004), roti tawar yang baik memiliki kriteria berupa tekstur yang lunak dan elastis. Pengamatan dilakukan setelah roti didiamkan beberapa jam setelah proses pemanggangan selesai.

Hasil pengamatan menunjukkan keempat perlakuan memiliki tekstur yang lembut dan elastis ketika ditarik seperti tekstur normal roti tawar pada umumnya. Hal ini menunjukkan bahwa tidak terdapat pengaruh spesifik pada tekstur roti berdasarkan perbedaan perlakuan emulsifier yang digunakan.

\section{Ukuran Pori Roti Tawar}

Pori-pori merupakan lubang kecil yang terbentuk karena gas $\mathrm{CO}_{2}$ yang dihasilkan oleh yeast pada proses fermentasi serta udara yang terperangkap di dalamnya (Surono et al., 2017). Struktur pori terbentuk selama proses pemanggangan. Pati yang tercampur dengan air lalu diberi perlakuan panas akan mengalami proses gelatinisasi sehingga terbentuklah jaringan roti. Partikel gluten yang terdapat dalam adonan akan menyebar, lalu adonan akan mengembang dan saling merajut membentuk kerangka adonan (Koswara, 2009). Pengukuran pori pada penelitian ini dilakukan dengan mengambil 10 sampel acak pori pada tiap produk roti untuk diukur diameternya $(\mathrm{mm})$ menggunakan penggaris.

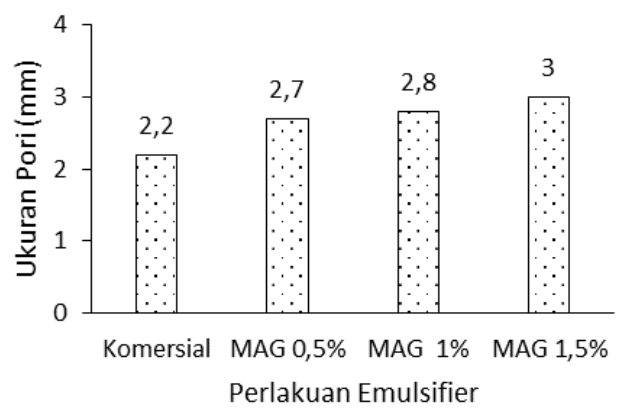

Gambar 5. Pengaruh perlakuan emulsifier terhadap rerata ukuran diameter pori $(\mathrm{mm})$ sampel produk roti 
Data pada Gambar 5 menujukkan adanya hubungan antara konsentrasi MAG dengan ukuran pori yang dihasilkan. Semakin besar konsentrasi MAG yang digunakan maka pori yang dihasilkan juga semakin besar. Ukuran pori erat kaitannya dengan kemampuan atau ketahanan gas yang dihasilkan oleh yeast pada adonan selama proses fermentasi. Dengan konsentrasi yang sama, MAG 1\% menghasilkan ukuran pori yang lebih besar dibandingkan emulsifier komersial. Menurut Pusuma et al. (2018), pori-pori roti yang baik adalah yang berukuran kecil dan seragam di seluruh bagian crumb. Analisis data dengan ANOVA diperoleh perbedaan ukuran pori keempat perlakuan tidak berbeda nyata.

\section{Ketahanan Umur Simpan Roti Tawar}

Umur simpan suatu produk ditentukan berdasarkan ketahanan produk tersebut dari kerusakan yang dapat terjadi selama proses penyimpanan. Kerusakan tersebut dapat berupa penurunan mutu produk baik secara fisik maupun kimiawi dan tumbuhnya mikroorganisme. Staling merupakan salah satu bentuk kerusakan pada roti yang membuat roti mengalami penurunan mutu karena adanya kerusakan fisik maupun kimiawi.

Emulsifier dapat memperkuat jaringan gluten sehingga kemampuan gluten menahan gas $\mathrm{CO}_{2}$ menjadi lebih kuat dan volume roti dapat meningkat serta mengikat amilosa agar tidak mengalami kristalisasi kembali sehingga dapat menghambat pengerasan selama penyimpanan. Menurut Hattori et al. (2015), MAG digunakan dalam industri pangan sebagai stabilisasi busa, meningkatkan penampilan produk, dan menghambat terjadinya staling.

Pengamatan umur simpan dilakukan dengan meletakkan sampel roti di dalam plastik transparan dan disimpan pada suhu ruang selama beberapa hari. Kondisi roti diamati setiap hari untuk mengamati lama penurunan kualitas roti. Hasil penelitian menunjukkan keseluruhan sampel perlakuan mengalami staling pada hari ketiga yang ditunjukkan dengan bagian crumb roti yang mulai mengeras dan crust roti mudah terlepas atau rapuh.

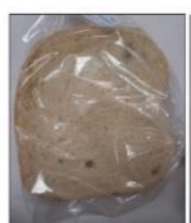

(a)

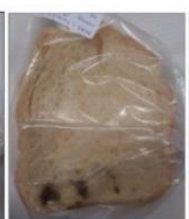

(b)

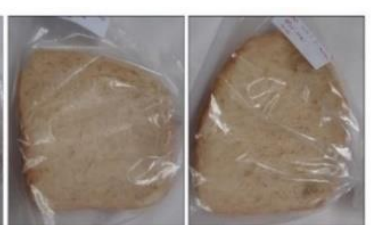

(c) (d)
Gambar 6. Hasil pengamatan pertumbuhan kapang pada hari keempat (a) komersial, (b) MAG $1 \%$, (c) MAG $1,5 \%$, (d) MAG $0,5 \%$

Menurut Koswara (2009), jenis kapang yang biasa tumbuh pada roti yaitu Aspergillus Sp. Tumbuhnya mikroorganisme pada roti disebabkan mikroorganisme tersebut menghidrolisis pati menjadi gula-gula sederhana yang merupakan sumber nutrisi utama mikroorganisme pada roti (Syorayah et al., 2012). Setelah dilakukan pengamatan, baik perlakuan emulsifier komersial dengan konsentrasi 1\%, MAG 1 $\%$ dan MAG 0,5\% memunculkan tanda-tanda kerusakan akibat adanya pertumbuhan kapang pada hari keempat, sedangkan untuk sampel MAG 1,5\% tanda-tanda kerusakan serupa baru terjadi pada hari kelima.

MAG yang digunakan pada penelitian ini terbuat dari hasil pengolahan crude palm oil (CPO). CPO terdiri dari asam lemak jenuh dan asam lemak tidak jenuh dengan komposisi yang imbang. Menurut Wang et al. (1993), MAG dari asam lemak rantai panjang jenuh ataupun tidak jenuh relatif tidak memiliki aktivitas antimikroba seperti MAG dari asam lemak rantai sedang. Hal tersebut menunjukkan pertumbuhan kapang yang lebih lama pada sampel MAG $1,5 \%$ bukan disebabkan dari pengaruh penambahan MAG. Pertumbuhan kapang salah satunya dapat disebabkan adanya kontaminan pada produk pangan. Hal ini mengindikasi bahwa pada ketiga perlakuan lain terdapat kontaminan yang membuat produk roti mengalami pertumbuhan kapang yang lebih cepat dibandingkan pada sampel roti MAG $1,5 \%$.

\section{Aplikasi MAG dalam Pembuatan Cookies \\ Daya Kembang}

Daya kembang cookies dipengaruhi oleh kadar protein. Protein akan mengalami denaturasi sehingga mengurangi daya kembang cookies karena granula pati sulit mengembang. Hal ini karena granula pati tanpa protein akan mudah pecah dan jumlah air yang masuk dalam granula pati akan lebih banyak sehingga pengembangan pati meningkat (Visita dan Putri, 2014). Menurut Estiasih (2005), saat pengadonan pati akan menyerap air dari bahan dan memerangkap udara sehingga membentuk gelembung udara kecil. Selanjutnya pada proses pemanggangan akan memicu terjadinya gelatinisasi yang diawali dengan pengembangan pati, pelelehan kristalin, pelarutan pati, penyebaran, pemekaran, dan pengembangan cookies.

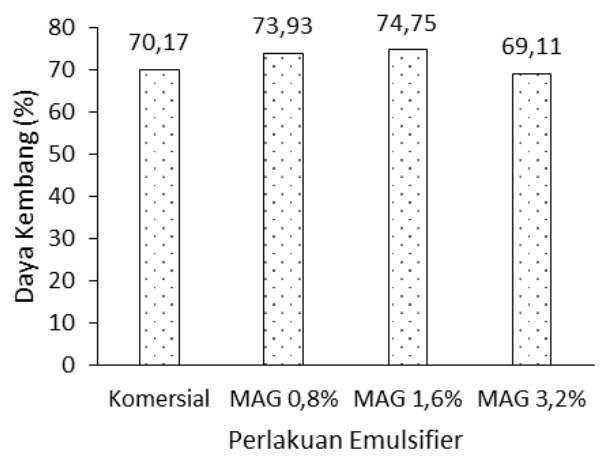

Gambar 7 Pengaruh perlakuan emulsifier terhadap daya kembang sampel produk cookies 
Hasil perhitungan terhadap daya kembang cookies dari keempat sampel perlakuan berkisar antara 69,11 - 74,75\%. Menurut Fu et al. (2018), MAG dapat meningkatkan volume dengan mendorong inklusi dan retensi udara dalam adonan cake. Dengan konsentrasi yang sama, perlakuan MAG 1,6\% menghasilkan daya kembang yang lebih besar daripada emulsifier komersial. Hal ini menunjukkan MAG memiliki daya pengembangan yang baik dibandingkan dengan emulsifier komersial.

\section{Warna, Rasa, Aroma Cookies}

Analisis warna, aroma, dan rasa cookies dilakukan melalui pengamatan mandiri. Menurut SNI 01-2973-1992, standar mutu cookies yang baik, yakni memiliki aroma normal, rasa tidak tengik, dan warna yang normal. Warna coklat khas pada cookies disebabkan adanya reaksi maillard ketika proses pemanggangan sebagai reaksi antara karbohidrat dan asam amino. Menurut Winarno (2002), panelis lebih menyukai biskuit dengan warna yang lebih cerah daripada biskuit dengan warna yang gelap. Hasil pengamatan pada keempat sampel cookies menunjukkan warna coklat cerah yang sama.

Reaksi maillard juga dapat mempengaruhi aroma yang dihasilkan. Menurut Arifin (2011), reaksi tersebut menyebabkan terjadinya perubahan yang ekstensif pada kandungan pati dengan eliminasi molekul air dan fragmentasi molekul gula di mana terjadi pemutusan ikatan karbon yang menghasilkan senyawa karbonil dan volatil sehingga menimbulkan aroma yang khas dari cookies. Aroma pada cookies juga dipengaruhi oleh beberapa bahan yang digunakan, terutama margarin yang memperkuat aroma pada cookies. Menurut Oktaviana et al. (2017), rerata panelis lebih menyukai cookies dengan aroma harum khas cookies. Aroma cookies tercium saat cookies dipanggang akibat adanya reaksi lemak yang ada pada formulasi cookies saat pemanggangan. Hasil pengamatan pada keempat sampel cookies menunjukkan aroma harum khas cookies yang sama.

Menurut Widiantara at al. (2018) berdasarkan uji organoleptik terhadap cookies, panelis lebih menyukai cookies dengan rasa yang manis. Rasa cookies berasal dari bahan pembentuk adonan seperti tepung, kuning telur, dan margarin. Hasil pengamatan pada keempat sampel cookies menunjukkan rasa lezat yang sama.

\section{Tekstur Cookies}

Tekstur cookies dapat dinilai berdasarkan aspek eksternal seperti tekstur lapisan kerak pada permukaan cookies dan aspek internal seperti tingkat kerenyahan cookies ketika dipatahkan. Permukaan cookies yang dihasilkan dapat bertekstur kering ataupun glossy (mengkilap). Kerenyahan cookies dapat dipengaruhi oleh komposisi cookies, waktu pemanggangan, dan suhu pemanggangan. Menurut Pratama et al. (2014), ketika cookies dipanggang maka kelembaban akan menurun dan membuat lapisan kerak menjadi kering yang mengakibatkan mengerasnya adonan cookies.

Hasil pengamatan menunjukkan cookies perlakuan emulsifier komersial dengan konsentrasi $1,6 \%$ menghasilkan tekstur yang lebih lembut dibandingkan dengan cookies perlakuan MAG, sedangkan cookies dengan MAG menunjukkan tingkat kerenyahan yang sama. Hal tersebut menunjukkan bahwa perbedaan konsentrasi MAG tidak mempengaruhi tingkat kerenyahan cookies, namun memberi hasil yang lebih renyah dibandingkan dengan emulsifier komersial. Tekstur cookies yang lebih lembut pada perlakuan emulsifier komersial dapat disebabkan kandungan sorbitol yang terkandung di dalamnya. Hal ini sesuai dengan pernyataan Majeed et al. (2018) bahwa penambahan sorbitol dapat meningkatkan kelembutan pada adonan.

Retakan yang dihasilkan pada permukaan cookies juga mempengaruhi mutu cookies yang dihasilkan. Hasil pengamatan menunjukkan jumlah retakan semakin berkurang seiring bertambahnya konsentrasi MAG yang ditambahkan. Menurut Oktaviana et al. (2017), tekstur cookies yang disukai adalah cookies yang renyah apabila dipatahkan, sehingga cookies dengan retakan yang lebih sedikit lebih disukai. Namun MAG 3,2\% tidak menghasilkan cookies dengan volume pengembangan yang paling baik. Hal ini menunjukkan jumlah retakan yang dihasilkan dari penambahan MAG tidak mempengaruhi volume yang dihasilkan.

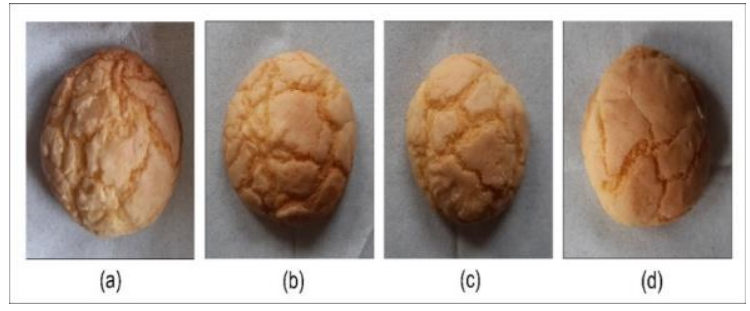

Gambar 8. Tekstur permukaan cookies (a) komersial, (b) MAG $0,8 \%$, (c) MAG 1,6\%, (d) MAG $3,2 \%$

\section{Ukuran Pori Cookies}

Pori merupakan salah satu faktor penentu mutu produk cookies yang dihasilkan. Struktur pori terbentuk selama proses pemanggangan. Berbeda dengan sponge cake dan roti, cookies memiliki pori yang berukuran lebih kecil. Menurut Subandoro et al. (2013), jumlah gluten yang sedikit dalam adonan menyebabkan adonan kurang mampu menahan gas, sehingga pori-pori yang terbentuk dalam adonan berukuran kecil. Pengukuran pori pada penelitian ini dilakukan dengan mengambil 10 sampel acak pori pada tiap produk cookies untuk diukur diameternya $(\mathrm{mm})$ menggunakan penggaris. 


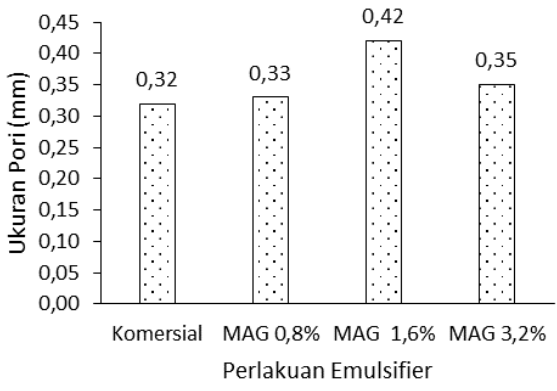

Gambar 9. Pengaruh perlakuan emulsifier terhadap rerata ukuran diameter pori (mm) sampel produk cookies

Berdasarkan data pada Gambar 9, diketahui cookies dengan perlakuan MAG 1,6\% menunjukkan ukuran pori yang paling besar. Menurut Pratama et al. (2014), gelembung udara dan uap air yang terbentuk dan mengembang pada adonan selama proses pemanggangan menunjukkan besarnya pengurangan densitas adonan. Struktur berpori terbuka inilah yang menyebabkan biskuit memiliki tekstur yang baik. Hasil ini sesuai dengan data volume pengembangan di mana cookies dengan perlakuan MAG 1,6\% menghasilkan volume pengembangan yang paling besar. Analisis data menggunakan ANOVA menunjukkan perbedaan ukuran pori keempat perlakuan cookies tidak berbeda nyata.

\section{KESIMPULAN DAN SARAN}

Mono-asilgliserol (MAG) hasil riset dapat digunakan sebagai emulsifier produk bakery dan memberikan pengaruh yang baik di beberapa aspek mutu seperti volume pengembangan, kestabilan daya kembang, dan warna produk yang lebih cerah. Penambahan MAG masih memiliki kelemahan dalam menghasilkan produk dengan struktur pori yang baik yang juga akan mempengaruhi tekstur yang dihasilkan. Hal tersebut dapat diatasi dengan penambahan sorbitol yang juga terkandung di dalam emulsifier komersial.

Konsentrasi MAG terbaik produk sponge cake yaitu 2,5\% berdasarkan hasil uji karakteristik fisik dan $3 \%$ berdasarkan organoleptik. Konsentrasi terbaik MAG pada produk roti tawar yakni $1 \%$ yang ditandai dengan dihasilkannya roti dengan volume yang lebih mengembang. Penambahan MAG tidak mempengaruhi rasa, aroma, dan tekstur, serta menghasilkan ukuran pori yang tidak berbeda nyata pada produk roti tawar. Konsentrasi terbaik MAG pada produk cookies yakni MAG 1,6\% yang ditandai dengan dihasilkannya cookies dengan volume yang lebih mengembang yang juga berpengaruh pada tingkat kerenyahan produk. Penambahan MAG tidak mempengaruhi warna, rasa, dan aroma, serta menghasilkan ukuran pori yang tidak berbeda nyata pada produk cookies.

\section{DAFTAR PUSTAKA}

[AOAC] Association of Official Analytical Chemists. 2005. Official Methods of Analysis. Washington (US): Benjamin Franklin Station.

Arifin S. 2011. Studi pembuatan roti dengan subtitusi tepung pisang kepok. [Skripsi]. Fakultas Pertanian Universitas Hasanuddin, Makasar.

Bornscheuer UT. 1995. Lipase-catalyzed syntheses of monoacylglycerols. Enzyme and Microbial Technology. 17(7): 578-586.

Damstrup ML, Jensen T, Sparso FP, Kiil SZ, Jensen AD, Xu X. 2005. Solvent optimization for efficient enzymatic monoacylglycerol production based on a glycerolysis reaction. Journal Amer Oil Chem Soc. 82: 559-564.

Dobraszczyk BJ, Smewing J, Albertini M, Maesmans G, Schofield SD. 2003. Extentional rheology and stability of gas cell walls in bread doughs at elevated temperatures in relation to breadmaking performance. Journal Cereal Chemistry. 80(2): 218-224.

Dziezak JD. 1988. Emulsifiers: the interfacial key to emulsion stability. Journal Food Technology. 42(10): 172-186.

Estiasih T. 2006. Teknologi dan Aplikasi Polisakarida dalam Pengolahan Pangan. Malang (ID: Fakultas Teknologi Pertanian. Universitas Brawijaya.

Fadhilah A. 2017. Pengaruh perbedaan warna bahan emulsifier terhadap mutu produk cake stabilizer produksi PT. Zeelandia Indonesia [skripsi]. Bogor (ID): Institut Pertanian Bogor.

Febrianto A. 2014. Kajian Karakteristik Fisikokimia dan Sensoris Tortilla Corn Chips dengan Variasi Larutan Alkali pada Proses Nikstamalisasi Jagung. Jurnal Teknosains Pangan. 3(3).

Ferretti CA, Spotty ML, danDi Cisimo JI. 2018. Diglyceride-rich oils from glycerolysis of edible vegetable oils. Catalysis Today. 302: 233-241.

Fitasari E. 2009. Pengaruh tingkat penambahan tepung terigu terhadap kadar air, kadar lemak, kadar protein, mikrostruktur, dan mutu organoleptik keju gouda olahan. Jurnal Ilmu dan Teknologi Hasil Ternak. 4(2): 17-29.

Fu Y, Zhao R, Zhang L, Bi Y, Zhang H, Chen C. 2017. Influence of acylglycerol emulsifier structure and composition on the function of shortening in layer cake. Food Chemistry. 249: 213-221.

Gandikota S dan MacRitchie F. 2005. Expansion Capacity of Dough: Methodology and Applications. Journal Cereal Science. 42: 157163.

Giannone V, Lauro MR, A, Spina A, Pasqualone A, Auditore L, Puglisi I, and Puglisi G. 2016. A novel $\alpha$-amylaselipase formulation as antistaling agent in durum wheat bread. Journal Food Science and Technology. 65: 381-389. 
Handlemen AR. 1961. Bubble mechanics in thick foams and their effects on cake quality. Journal Cereal Chem. 38(3): 294.

Hartomo AJ dan Widiatmoko MC. 1993. Emulsi dan Pangan Instan Ber-lesitin. Yogyakarta (ID): Andi Offset.

Hasenhuettl GL. 2008. Food Emulsifiers and Their Applications. Editor Hasenhuettl dan Hartel. New York (US): Springer Science.

Hattori K, Dupuis B, Fu BX, Edwards NM. 2015. Effects of monoglycerides of varying fatty acid chain length and mixtures thereof on spongeand-dough breadmaking quality. Cereal Chemistry. 92(5): 481-486.

Ketaren. 2008. Pengantar Teknologi Minyak dan Lemak Pangan. Jakarta (ID): UI Pr.

Koswara S. 2009. Teknologi Pengolahan Roti. eBookPangan.com

Majeed M, Mahmood MA, Khan MU, Fazel M, Shariati MA, Pigorev I. 2018. Effect of sorbitol on dough rheology and quality of sugar replaced cookies. Slovak Journal. Food Sciences. 12(1): 50-56.

Mardaweni R. 2016. Pemurnian Mono-Diasilgliserol Hasil Ekstraksi Palm Fatty Acid Distillate dan Gliserol dengan Ekstraksi Pelarut Saponifikasi dan Destilasi Molekuler. [Tesis]. Bogor (ID): Institut Pertanian Bogor.

Mudjajanto ES dan Yulianti LN. 2004. Membuat Aneka Roti. Jakarta (ID): Penebar Swadaya.

Mudjisihono R, Munarso SJ, dan Noor Z. 2003. Pengaruh penambahan tepung kacang hijau dan gliseril monostearat pada tepung jagung terhadap sifat fisik dan organoleptik roti tawar yang dihasilkan. Agritech. 13(4):1-6.

Musfiroh I, Indriyati W, Muchtaridi, Setiya Y. 2009. Analisis proksimat dan penetapan kadar Bkaroten dalam selai lembaran terung belanda dengan metode spektrometri sinar tampak. Jurnal. Penelitian Fakultas Farmasi Universitas Padjajaran. Bandung (ID).

O'Brien RD. 2009. Fats and Oil: Formulating and Processing for Application. Edisi ketiga. Boca Raton (US): CRC Pr.

Oktaviana AS, Hersoelistyorini, dan Nurhidajah. 2017. Kadar protein, daya kembang, dan organoleptik cookies dengan substitusi tepung mocaf dan tepung pisang kepok. Jurnal Pangan dan Gizi. 7(2): 72-81.

Praseptiangga D, Aviany TP, dan Parnanto NHR. 2016. Pengaruh penambahan gum arab terhadap karakteristik fisikokimia dan sensoris fruit leather nanga. Jurnal Teknologi Hasil Pertanian. 9(10): 71-83.

Prasetyowati SP. 2010. Pengaruh penggunaan tepung kecambah kacang hijau (phaseoulus radiatus $l$.) dan tepung jagung (zea mays $l$.) untuk substitusi terigu terhadap sifat fisikokimia dan sensoris cookies. [Skripsi]. Surakarta (ID): Universitas Sebelas Maret.

Pratama RI, Rostini I, dan Liviawaty E. 2014. Karakteristik biskuit dengan penambahan tepung tulang ikan jangilus (Istiophorus Sp.). Jurnal Akuatika. 5(1): 30-39.

Pusuma DA, Praptiningsih Y, dan Choiron M. 2018. Karakteristik roti tawar kaya serat yang didistribusi menggunakan tepung ampas kelapa. Jurnal Agroreknologi. 12(1): 29-42.

Rumondang I, Setyaningsih D, dan Hermanda A. 2016. Hasil riset mono-diasilgliserol berbasis gliserol dan palm fatty acid distillate. Jurnal Kimia dan Kemasan. 38(1): 1-6.

Setyaningsih D, Bashir B Al, Silalahi VH, Muna N. 2016. Purification of Mono-Diacylglycerol through Saponification and Solvent Extraction. International Journal Envitonment Bioenergy. 11(1):1-11.

Setyaningsih D, Faqih IN, Neli M, Qatrinada RJ, Syafira S. 2021. Synthesis of mono diacyl glycerol from palm fatty acid distillate and glycerol as antistatic agents on plastics. IOP Conf. Series: Earth and Environmental Science 749 (2021) $012012 \quad$ IOP Publishing. doi:10.1088/1755-1315/749/1/01201

[SNI] Standar Nasional Indonesia. 1995. SNI 013840-1995: Syarat Mutu Roti Manis. Jakarta (ID): SNI.

[SNI] Standar Nasional Indonesia. 2006. SNI 012346-2006: Petunjuk Pengujian Organoleptik dan atau Sensori. Jakarta (ID): SNI.

Soliha I. 2008. Aplikasi penggunaan tepung daging sapi sebagai bahan substitusi sebagian tepung terigu dalam pembuatan cookies. [Skripsi]. Bogor (ID): Insitut Pertanian Bogor.

Subandoro RH, Basito, dan Atmaka W. 2013. Pemanfaatan tepung millet kuning dan tepung ubi jalar kuning sebagai substitusi tepung terigu dalam pembuatan cookies terhadap karakteristik organoleptik dan fisikokimia. Jurnal Teknosains Pangan. 2(4).

Suhardjito. 2003. Pastry dalam Perhotelan. Yogyakarta (ID): Andi.

Suhardi. 1988. Kimia dan Teknologi Protein. Yogyakarta (ID): Universitas Gadjah Mada.

Sulistianing R. 1995. Pembuatan dan optimisasi formula roti tawar dan roti manis skala kecil [skripsi]. Bogor (ID): Institut Pertanian Bogor.

Surono DI, Nurali EJN, dan Moningka MS. 2017. Kualitas fisik dan sensoris roti tawar bebas gluten bebas kasein berbahan dasar tepung komposit pisang goroho (Musa acuminate L). Jurnal Teknologi Pertanian. 1(1): 1-12.

Susiwi S. 2009. Penentuan Kadaluwarsa Produk Pangan. Bandung (ID): Universitas Pendidikan Indonesia.

Syorayah I, Nuraini D, V dan hayaya I. 2013. Analisis kandungan boraks $\left(\mathrm{Na}_{2} \mathrm{~B}_{4} \mathrm{O}_{7} 10 \mathrm{H}_{2} \mathrm{O}\right)$ pada roti 
tawar yang bermerek dan tidak bermerek yang dijual di kelurahan padang bulan kota medan. [Skripsi]. Medan (ID): Universitas Sumatera Utara.

Visita BF dan Putri WDR. 2014. Pengaruh penambahan bubuk mawar merah (Rosa domascene mill) dengan jenis bahan pengisi berbeda pada cookies. Jurnal Pangan dan Agroindustri. 2(1): 39-46.
Wang LL, Yang BK, Parkin KL, Johnson EA. 1993. Inhibition of Listeria monocytogenes by monoacylglycerols synthesized from coconut oil and milk fat by lipasecatalyzed glycerolysis. Joural Agriculture Food Chemical. 41: 10001005.

Winarno FG. 2002. Kimia Pangan dan Gizi. Jakarta (ID): Gramedia Pustaka Utama. 